\title{
脂肪酶催化缩聚法合成可完全降解的聚羟基丙酸酯
}

\author{
宋 昊 ${ }^{1,2}$, 赵永杰 ${ }^{1}$, 张颖金金 ${ }^{1,2}$, 孔维宝 ${ }^{1,2}$, 夏春谷 ${ }^{1, *}$ \\ ${ }^{1}$ 中国科学院兰州化学物理研究所羰基合成与选择氧化国家重点实验室, 甘肃兰州 730000 \\ 2 中国科学院研究生院, 北京 100049
}

\begin{abstract}
摘要: 以 3-羟基丙酸甲酯为聚合单体, 建立了以固定化脂肪酶 Novozym 435 为催化剂的酶催化缩聚反应体系, 合成可完全降 解的高分子聚酯聚羟基丙酸酯, 考察了反应条件和介质对反应性能的影响, 结果表明, 纯度大于 $95 \%$ 的单体即可在温和条件下 合成聚羟基羧酸酯; 降低反应压力可有效提升产物产率和分子量. 通过选择合适的有机溶剂介质和表面活性剂, 可使产物分子 量提升至 $13000\left(M_{\mathrm{w}}\right)$ 以上. 脂肪酶催化剂重复利用能力优异, 经 6 批次反应后, 其相对活性保持在 $95 \%$ 以上.

关键词: 聚羟基羧酸酯; 聚合; 酶催化; 脂肪酶; 3-差基丙酸甲酯
\end{abstract}

中图分类号: O643 文献标识码: A

收稿日期: 2011-09-19. 接受日期: 2011-11-07.

*通讯联系人. 电话: (0931)4968058; 传真: (0931)4968129; 电子信箱: cgxia@1zb.ac.cn

基金来源: 国家自然科学基金(21133011).

本文的英文电子版(国际版)由Elsevier出版社在ScienceDirect上出版(http://www.sciencedirect.com/science/journal/18722067).

\section{Synthesis of Polyhydroxyalkanoates by Polymerization of Methyl 3-Hydroxypropionate in the Catalysis of Lipase}

\author{
SONG Hao ${ }^{1,2}$, ZHAO Yongjie ${ }^{1}$, ZHANG Yingxin ${ }^{1,2}$, KONG Weibao $^{1,2}$, XIA Chungu ${ }^{1, *}$ \\ ${ }^{1}$ State Key Laboratory for Oxo Synthesis and Selective Oxidation, Lanzhou Institute of Chemical Physics, Chinese Academy of Sciences, \\ Lanzhou 730000, Gansu, China \\ ${ }^{2}$ Graduate University of Chinese Academy of Sciences, Beijing 100049, China
}

\begin{abstract}
The polymerization of methyl 3-hydroxypropionate as monomer catalyzed by lipase was selected as a model system in this study. The monomer with the purity around $95 \%$ could be polymerized to polyhydroxyalkanoates in the catalysis of Novozym 435 . Decreasing the reaction pressure would result in the increase of product yield and high molecular weight. By choosing appropriate organic solvents, surfactants and reaction pressure, the molecular weight of polyhydroxy propionate polyester could be controlled from 1800 to $13000\left(\mathrm{M}_{\mathrm{w}} \mathrm{value}\right)$. The reusing ability of enzymatic catalyst was comparatively good. The relative activity could be maintained above $95 \%$ after 6 repeated batches reaction.
\end{abstract}

Key words: polyhydroxyalkanoates; polymerization; enzyme catalysis; lipase; methyl 3-hydroxypropionate

Received 19 September 2011. Accepted 7 November 2011.

*Corresponding author.Tel: +86-931-4968058; Fax: +86-931-4968129; E-mail: cgxia@lzb.ac.cn

This work was supported by the National Natural Science Foundation of China (21133011).

English edition available online at Elsevier ScienceDirect (http://www.sciencedirect.com/science/journal/18722067).

Polyhydroxyalkanoates (PHAs) have been demonstrated to be a family of biopolymers with good biodegradability and biocompatibility. Due to the biological degradability and the extraordinary properties similar to those of common thermoplastics or elastomers, PHAs have several very useful potential applications, especially in medicine and agri- culture [1-3]. Natural biodegradable polyesters are widespread in many kinds of microbial cells. More than 300 different microorganisms are known to synthesize and accumulate PHAs in their cells. Bacterial fermentation of PHAs has become an environment-friendly and efficient method, by which some commercial products of PHAs have 
been obtained successfully [4-6]. But there are some limitations in the traditional fermentation process of PHAs. Firstly, the special unbalanced nutrient conditions needed by PHAs synthesis will lead to slow cell growth and low product yield. Secondly, the carbon sources used in fermentation for synthesizing PHAs are comparatively expensive. Thirdly, the separation and purification of PHAs in cells are complex and expensive processes [7]. These limitations lead to the high PHAs price compared with petrochemical-based polymers. The commercial applications of PHAs are limited due to the cost [8].

The enzyme-catalyzed polymerization has been regarded as a new environment-friendly synthetic process for polymeric materials, providing some good examples of "green polymer chemistry" [9]. The polyesters can be synthesized through the ring-opening polymerization, polycondensation, and transesterification catalyzed by enzyme [10-13]. The enzyme-catalyzed polymerization has many distinct advantages, such as mild reaction conditions, excellent recycle ability and high region-selectivity [14]. The enzyme-catalyzed polymerization does not require the exclusion of water or air. Enzymes can also be used in bulk, organic media, and at various interfaces, which give them an extra edge over the use of organo-metallic catalysts [15-18]. Most enzyme-catalyzed polymerization of PHAs are about ring-opening reactions of lactones [19]. The reported linear hydroxyester monomers of polycondensation included hydroxybutyrate, hydroxypentanoate, and hydroxyhexanoate [20-22]. In these reports, the molecular weight was relatively low and the monomer conversion was inefficient. The reactions were conducted commonly in the organic solvents or ionic liquids. The byproducts of macrolactones were produced with linear polyesters. Although some good examples of the enzyme-catalyzed polymerization of PHAs were well known, the polymerization of the linear chemical monomer, polyhydroxypropionate, catalyzed by enzyme has not been reported [23].
The enzymatic synthesis of polyesters from hydroxyester was proposed to proceed in three parts [19]: initial rapid transesterification (Scheme 1), followed by intermediate polymerization with a significant molecular weight increase, and finally slow polymerization reaching the maximum of the molecular weight. The polyester would also undergo degradation via alcoholysis.

In this article, we report the polymerization of methyl 3-hydroxypropionate as monomer catalyzed by lipase (Scheme 2). The product of polyhydroxypropionate polyester (the simplest type of PHAs) was obtained under mild conditions. Compared with the microorganism fermentation, it was a more convenient and inexpensive process. The simple purification of products and using synthetic chemical monomer (methyl 3-hydroxypropionate could be obtained by a simple chemical synthesis process with low costs in our laboratory) could reduce the costs of the polymerization obviously. The enzyme-catalyst could also be used repeatedly. Furthermore, the molecular weight of polyester could be controlled by changing the reaction conditions, which was unavailable in the traditional microorganism fermentation of PHAs.

\section{Experimental}

\subsection{Enzymes and chemicals}

Four lipases, Novozym 435 (lipase acrylic resin from Candida antarctica, 10 units/mg solid), PPL (lipase from porcine pancreas, 55 units/mg solid), CRL (lipase from Candida rugosa, 1140 units/mg solid), and L-PS (Amano lipase PS from Burkholderia cepacia, 30 units/mg solid), were purchased from Sigma and used without treatment.

Methyl 3-hydroxypropionate with above 95\% purity was obtained in our laboratory by methoxycarbonylation of propylene oxide [24-25], which was the most simple and economic synthetic method in this field. The synthetic

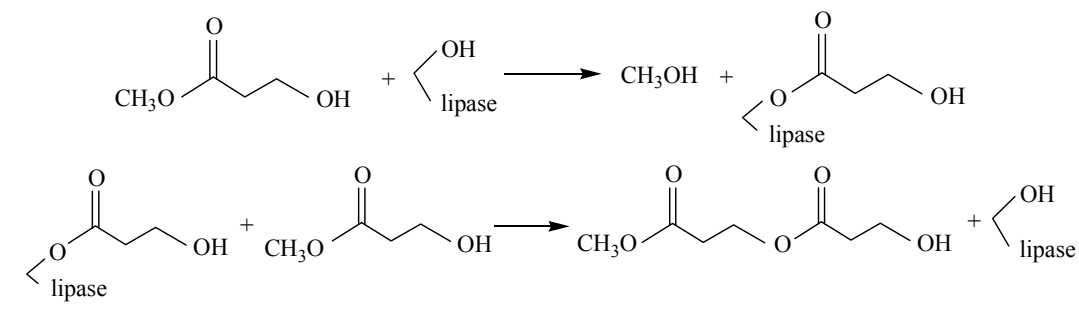

Scheme 1. Mechanism of step-growth polymerization in the catalysis of lipase.<smiles>CC[C+]CCC(=O)OC(C)(C)COCCC(=O)OC</smiles>

Methyl 3-hydroxypropionate Polyhydroxy propionate polyester

Scheme 2. Polymerization of methyl 3-hydroxypropionate in the catalysis of lipase. 
product could be used directly in the enzyme-catalyzed polymerization. The purification of monomer was not needed, which could reduce greatly the costs of polymeric substrates. On the other hand, it was very difficult to complete polymerization by monomer with such low purity in the catalysis of organo- metallic catalysts.

All other chemicals and reagents were of analytical grade.

\subsection{General procedure for the lipase-catalyzed reaction}

The enzyme-catalyzed reaction was performed in a solvent-free system by mixing the substrate of methyl 3-hydroxypropionate $(100 \mathrm{mmol})$ and lipase (preset concentration, $\mathrm{wt} \%)$ in a round-bottom flask $(50 \mathrm{ml})$. The flask was then placed into a constant temperature oil bath on a magnetic stirrer at $1000 \mathrm{r} / \mathrm{min}$. Vacuum was applied to facilitate removal of methanol (byproduct in the polymerization). Since methyl 3-hydroxypropionate was relatively volatile, the loss of monomer under pressure should be considered. Thus, a cold trap was used for recovering substrate. After reaction, the products and unreacted monomers were extracted with chloroform. The mixture was stirred for $10 \mathrm{~min}$, and the undissolved lipase was filtrated. The methanol at 4 ${ }^{\circ} \mathrm{C}$ was dropped into the chloroform phase, and then the white solid products of polyhydroxy propionate were precipitated by cold methanol. The polyester was separated by filtration, washed twice with methanol, and dried at $60{ }^{\circ} \mathrm{C}$ for $2 \mathrm{~h}$. At the same time, the lipase could be reused.

The yield of polyhydroxy propionate polyester was calculated by Yield $=\frac{\text { obtained product }(\mathrm{g})}{\text { theoretical procuct }(\mathrm{g})} \times 100 \%$, where the theoretical product amount $(\mathrm{g})=\frac{7.2 \times \text { substrate amount }(\mathrm{g})}{10.4}$.

The polymerization product was confirmed by NMR. The spectra were recorded on a Varian INOVA spectrometer in $\mathrm{CDCl}_{3}$ at $30{ }^{\circ} \mathrm{C}\left({ }^{1} \mathrm{H}\right.$ NMR $400 \mathrm{MHz},{ }^{13} \mathrm{C}$ NMR $\left.100 \mathrm{MHz}\right)$.

The molecular weight and its distribution were determined by the GPC system (Styragel HT 3, 5, 6 E in series using HPLC (Waters 2695, USA)/RID (Waters 2414, USA)). Polystyrene was used as a standard reference (solvent, $0.1 \mathrm{mg} / \mathrm{ml}$ chloroform).

The monomer concentration was analyzed by an Agilent 6820 gas chromatograph equipped with a flame ionization detector and a SE-54 capillary column $(50 \mathrm{~m} \times 0.32 \mathrm{~mm} \times$ $2.00 \mathrm{~mm})$.

\subsection{Water activity}

Lipase and substrates were absorbed or equilibrated with solid sorbent or saturated salt solutions at $25{ }^{\circ} \mathrm{C}$ in separate closed containers [26]. The solid sorbent and salts used were molecular sieve $3 \mathrm{~A}\left(a_{w}<0.01\right), \mathrm{LiBr}\left(a_{w}=0.06\right), \mathrm{LiCl}$ $\left(a_{w}=0.11\right), \mathrm{MgCl}_{2}\left(a_{w}=0.33\right), \mathrm{Mg}\left(\mathrm{NO}_{3}\right)_{2}\left(a_{w}=0.54\right)$, and $\mathrm{NaCl}\left(a_{w}=0.75\right)$. Absorption or equilibration was performed for at least $48 \mathrm{~h}$.

\section{Results and discussion}

\subsection{Enzyme selection}

We compared the lipase-catalyzed polymerization of methyl 3-hydroxypropionate by using four different lipases with $1 \%-10 \%$ dosage (relative to monomer). The results showed that L-PS and CRL failed to catalyze the polymerization in the selected temperature range from 30 to $100{ }^{\circ} \mathrm{C}$. The PPL (10 wt $\%$ catalyst: monomers; 55 units $/ \mathrm{mg}$ ) catalyzed the reaction with $7.3 \%$ product yield at $60{ }^{\circ} \mathrm{C}$. Novozym 435 performed excellent catalyst activity, because $85.1 \%$ product yield could be achieved by using smaller amount (3 wt $\%$ catalyst: monomers; 10 units $/ \mathrm{mg}$ ) of the enzyme-catalyst.

The white polyhydroxypropionate polyester was obtained under mild conditions by using Novozym 435 as catalyst. The polymer dissolved in some organic solvents such as chloroform and dichloromethane, but could not dissolve in methanol, ethanol or water. The melting point of polymer was $52.8^{\circ} \mathrm{C}, M_{w}$ value was about 2300 and polydispersity $\left(M_{w} / M_{n}\right)$ was 1.07 .

\subsection{Optimization of polymeric reaction conditions}

\subsubsection{Effect of catalyst dosage}

The selected catalyst dosages were $1 \mathrm{wt} \%, 3 \mathrm{wt} \%, 5 \mathrm{wt} \%$, $10 \mathrm{wt} \%$ (relative to monomer) in this study. The results showed that high conversion ratio was obtained by increasing the catalyst dosage. But the change was not obviously when enzyme dosage was increased from $3 \mathrm{wt} \%$ to $10 \mathrm{wt} \%$. The molecular weight was not affected by the different catalyst dosages (Table 1). Considering costs, $3 \mathrm{wt} \%$ was chosen as the optimum catalyst dosage in the latter studies.

\subsubsection{Effect of monomer purity}

The monomer with $95 \%$ purity was obtained by meth-

Table 1 Effect of Novozym 435 catalyst dosage

\begin{tabular}{cccc}
\hline Catalyst dosage (wt\%) & $M_{w}$ & $M_{w} / M_{n}$ & Yield (\%) \\
\hline 0 & - & - & 0 \\
1 & 2159 & 1.05 & 67.5 \\
3 & 2286 & 1.07 & 85.1 \\
5 & 2423 & 1.08 & 86.2 \\
10 & 2072 & 1.06 & 88.1 \\
\hline
\end{tabular}

Reaction conditions: $55^{\circ} \mathrm{C}, 30 \mathrm{~h}$, solvent-free, $80 \mathrm{kPa}$. 
oxycarbonylation of propylene oxide. They could be used directly in the polymeric reaction with good results. The impurity in monomer didn't result in inactivation of enzyme catalyst. Further purification of monomer would improve product yield slightly, but the optimal reaction time would be shortened from 30 to $23 \mathrm{~h}$ when using monomer with $99.5 \%$ purity. There was no obvious effect on molecular weight by using high purity monomer (Table 2).

Table 2 Effect of monomer purity

\begin{tabular}{cccc}
\hline Monomer purity (\%) & $M_{w}$ & Yield (\%) & Optimal reaction time (h) \\
\hline 95 & 2286 & 85.1 & 30 \\
98 & 2235 & 85.9 & 28 \\
99.5 & 2329 & 86.8 & 23 \\
\hline
\end{tabular}

Reaction conditions: $3 \mathrm{wt} \%$ Novozym $435,55^{\circ} \mathrm{C}$, solvent-free, $80 \mathrm{kPa}$.

\subsubsection{Effect of reaction temperature}

The polymeric reactions were performed at $35,45,50$, $55,60,65$, and $75{ }^{\circ} \mathrm{C}$, respectively. Figure 1 shows the product yields at different temperature in the range of 35-75 ${ }^{\circ} \mathrm{C}$. When the temperature increased from 35 to $55^{\circ} \mathrm{C}$, the product yields increased obviously. But a distinct decrease appeared at higher temperature. The optimum reaction temperature was $55{ }^{\circ} \mathrm{C}$ and the product yield achieved $85.1 \%$ after $30 \mathrm{~h}$ polymerization. As a well-known lipase catalyst, Novozym 435 had shown good stability when the reaction temperature was above $55^{\circ} \mathrm{C}$ in many reports [19,21,27]. The enzyme activity would not be affected in the selected temperature range. So the change of enzyme activity was not the major reason for the product yields decreasing with the temperature increasing. Because of the volatility, more and more substrates lost under the pressure with increasing the temperature, which should be the reason for the product yields decreasing.

There was no significant change of molecular weight when the temperature enhanced from 35 to $55^{\circ} \mathrm{C}$. However,

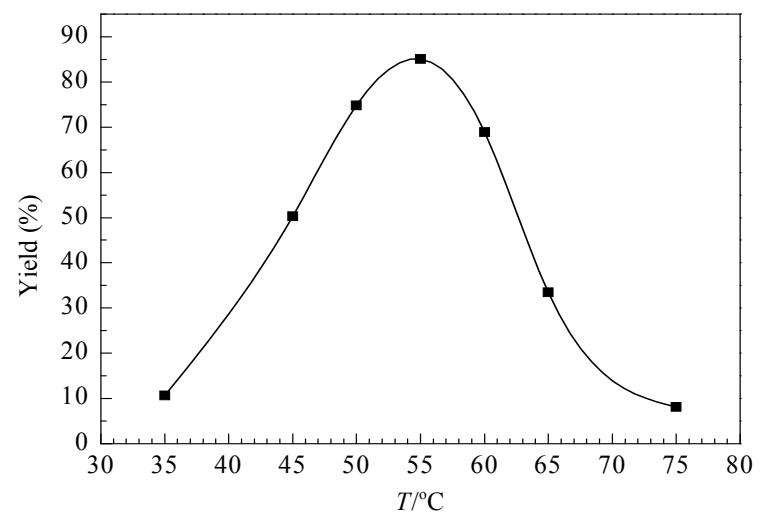

Fig. 1. Effect of reaction temperature on product yield. Reaction conditions: 3 wt $\%$ Novozym 435, 30 h, solvent-free, $80 \mathrm{kPa}$. a small increase (from $M_{w} 2300$ to 4800) was observed when the temperature reached $70{ }^{\circ} \mathrm{C}$. The polydispersity $\left(M_{w} / M_{n}\right)$ of polymer increased simultaneously from 1.07 to 1.30 with the temperature increasing from 55 to $70{ }^{\circ} \mathrm{C}$. It was above 1.40 when the temperature was further increased.

\subsubsection{Effect of water activity}

Water activity has been recognized as a key parameter which determines the enzymatic activity. The physical properties of the enzymes depend on the hydration state of the proteins, which is influenced by the water activity.

The water activity of polymeric reaction of methyl 3-hydroxypropionate was controlled in the range from 0.01 to 0.75 . The effect of water activity was shown in Fig. 2.

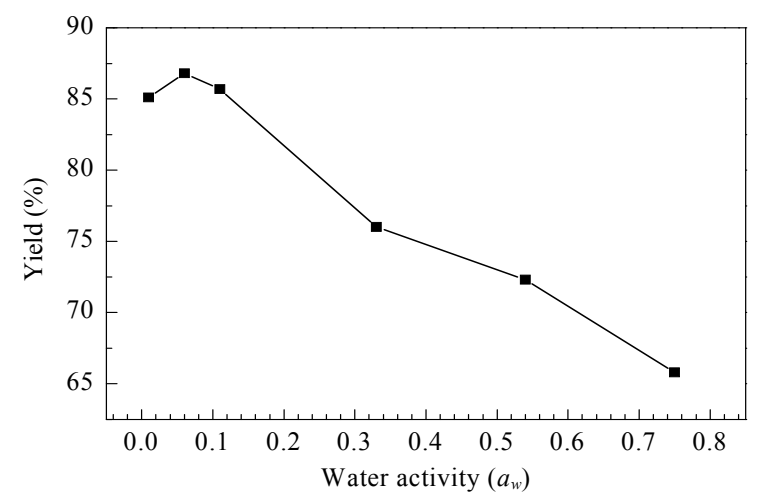

Fig. 2. Effect of water activity on product yield. Reaction conditions: $3 \mathrm{wt} \%$ Novozym $435,55^{\circ} \mathrm{C}, 30 \mathrm{~h}$, solvent-free, $80 \mathrm{kPa}$.

Most enzymes were known to require high water activity to obtain high activity. However, some lipases showed a different behavior [26]. They were relatively active at low water activity and some even showed an optimal activity in the region below 0.3 . It was showed that lipases were different from other enzymes in the respect of the water requirement. From Fig. 2, the product yields were similar at water activities between 0.01 and 0.11 , but it decreased as the water activity increased. The possible reasons were: (1) Excessive water molecule accumulated on the surface of lipase with increasing the water concentration in the system, which might prevent hydrophobic groups of monomer from approaching enzyme molecule; (2) High water concentration would also lead to degradation of short-chain oligomer, which was not helpful to obtain high molecular weight polymer. So the water activity in this study was controlled at the lowest value $(<0.01)$ by preequilibrating of molecular sieve $3 \mathrm{~A}$.

\subsubsection{Effect of reaction time}

Figure 3 shows that the curve of the monomer conversion 
was similar with that of the product yield. The initial reaction rate measured was $12.1 \mathrm{mmol} /(\mathrm{h} \cdot \mathrm{g})$. Under the optimum condition $\left(55^{\circ} \mathrm{C}, 3 \mathrm{wt} \%\right.$ Novozym $\left.435,80 \mathrm{kPa}\right)$, the product yield achieved at $80 \%$ during the first $26 \mathrm{~h}$. After that, the product yield increased slowly with prolonging the reaction time. At the time of $30 \mathrm{~h}$, the product yield was improved to $85.1 \%$. Then, the reaction reached equilibrium and the product yield remained almost unchanged. So the optimal polymeric reaction time was $30 \mathrm{~h}$.

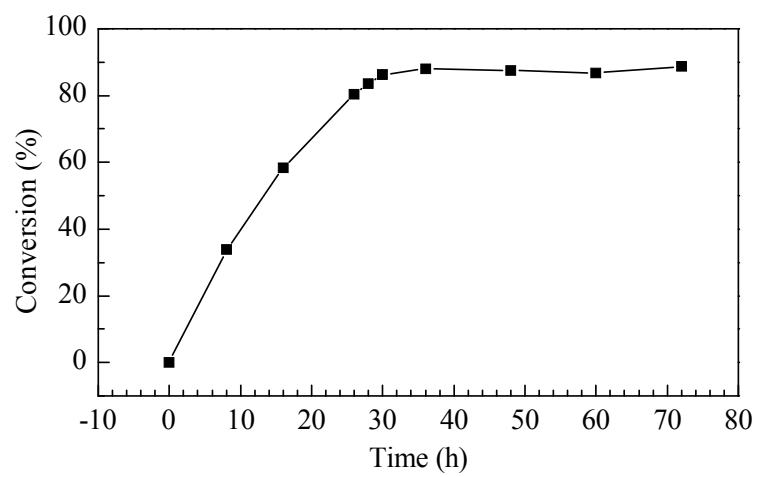

Fig. 3. Monomer conversion as a function of reaction time. Reaction conditions: $3 \mathrm{wt} \%$ Novozym $435,55^{\circ} \mathrm{C}$, solvent-free, $80 \mathrm{kPa}$.

\subsection{Control of the molecular weight}

\subsubsection{Effect of reaction pressure}

In the most cases of enzyme-catalyzed polymerization, in order to obtain the high molecular weight products as well as the high product yield, high vacuum was employed to remove the byproducts, such as water and alcohol. The reaction pressure had great effect on the enzyme-catalyzed polymerization of methyl 3-hydroxypropionate. In the reaction, the presence of methanol as byproduct was harmful for the polymerization. Under the normal pressure, the polymerization would not be completed because of the chemical equilibrium of the reaction. Methanol could be eliminated absolutely by increasing the vacuum of the system, which would shift the chemical equilibrium towards polymerization. Thus, the preceding polymeric reactions were conducted under the pressure of $80 \mathrm{kPa}$.

High vacuum was also helpful for the molecular weight and the product yield of polyhydroxy propionate polyester. Table 3 shows that the product yield and the molecular weight were improved with decreasing the pressure from 101.3 to $19.6 \mathrm{kPa}$. The molecular weight of polymer achieved about $M_{w} 13100$ and the product yield was $89.1 \%$ under the low pressure of $19.6 \mathrm{kPa}$.

\subsubsection{Effect of organic solvent system}

Using free-solvent system in polymeric reaction had
Table 3 Effect of reaction pressure on the polymerization

\begin{tabular}{cccc}
\hline$p / \mathrm{kPa}$ & $M_{w}$ & $M_{w} / M_{n}$ & Yield (\%) \\
\hline 101.3 & 2135 & 1.10 & 76.1 \\
80 & 2286 & 1.07 & 85.1 \\
40 & 6834 & 1.34 & 88.2 \\
19.6 & 13128 & 1.43 & 89.1 \\
\hline
\end{tabular}

Reaction conditions: $3 \mathrm{wt} \%$ Novozym $435,55^{\circ} \mathrm{C}, 30 \mathrm{~h}$, solvent-free.

many advantages, such as rapid reaction rate, convenient products separation, and enzyme activity preservation. But the viscosity of oligomers increased rapidly with the reaction processed in the free-solvent system. The speed and intensity of the stirrer were decreased by gel or soft solid oligomers, which was not benefit to the normal polymeric reaction. In this study, the stirrer was stopped because of the abundant sticky solid oligomers with low molecular weight. To improve the polymerization, we chose some different organic solvents to decrease the oligomers viscosity and make sure the reaction could continue.

The solvent polarity and the substrate solubility often showed great influence on enzyme activity. Table 4 shows that some organic solvents didn't promote polymerization of methyl 3-hydroxypropionate. Because of inhibiting effect of enzyme activity, the product yield decreased obviously in high polar organic solvent systems. But some organic solvents with high value of hydrophobic parameter $(\log P)$ were benefit to molecular weight. For example, the $M_{w}$ value enhanced from 2300 to 3300 and 3500 in the diphenyl ether and isooctane system, respectively.

Table 4 Effect of organic solvent system on polymerization

\begin{tabular}{lcccc}
\hline Solvent & $\log P \mathrm{o} / \mathrm{w}$ & $M_{w}$ & $M_{w} / M_{n}$ & Yield (\%) \\
\hline Solvent-free & - & 2286 & 1.07 & 85.1 \\
Tetrahydrofuran & 0.46 & 2135 & 1.12 & 49.2 \\
Cyclohexane & 3.4 & 1992 & 1.04 & 75.0 \\
Chloroform & 1.94 & 2090 & 1.05 & 53.7 \\
Toluene & 2.69 & 2644 & 1.07 & 78.3 \\
1,4-Dioxane & -0.42 & 2269 & 1.11 & 57.7 \\
Diphenyl ether & 4.2 & 3287 & 1.12 & 82.6 \\
Isooctane & 4.5 & 3532 & 1.09 & 83.9 \\
\hline
\end{tabular}

Reaction conditions: 3 wt $\%$ Novozym $435,55^{\circ} \mathrm{C}, 30 \mathrm{~h}, 80 \mathrm{kPa}$, different organic solvents (equal volume with substrate).

The inhibiting effect of solvent polarity on enzyme activity was attributed to the solvent's ability to trap enzyme from the essential water layer, or to penetrate into the water layer, then break the interaction between water and enzyme molecule. Therefore, the inhibiting effect on enzyme activity was unobvious when the solvent was highly hydrophobic. The more hydrophobic of the solvent, the larger the hydrophobic parameter $(\log P)$ was. The $\log P$ values of the selected organic solvents were in the range from -0.42 to 4.5. The molecular weight of the products was increased 
when $\log P$ was more than 4.0. The product yield was maintained above $80 \%$ in the same solvent systems. But the product yield decreased obviously with increasing the hydrophilic of the solvents, especially when $\log P$ was less than 2.0. The combined water molecule could be separated from the enzyme surface by hydrophilic solvents, which resulted in the inactivation of enzyme. The enzyme molecular conformation would also be changed by the interaction between enzyme protein and the intensive polar solvents, which was harmful for the contact between enzyme active centers and substrates. In the polymeric reaction system of methyl 3-hydroxypropionate, it was concluded that polymer chain-increasing was enhanced in hydrophobic solvents with high $\log P$ value $(>4.0)$.

\subsubsection{Effect of surfactants}

The surfactants were very important for adjusting lipase activity and molecular weight. Adding appropriate surfactants would create enormous water-oil interface which was needed in lipase catalysis. The results in Table 5 shows that the constricted lipase conformation was expanded by adding the right surfactant with concentration of $30 \mathrm{mg} / \mathrm{ml}$ into the reaction system, which improved the degree of polymerization. Two surfactants (Triton X-100 and Triton X-114) had notable effect on the molecular weight of the products. The $M_{w}$ value reached 9800 by using Triton X-100 as surfactant.

Table 5 Effect of surfactants on polymerization

\begin{tabular}{lccc}
\hline Surfactant & $M_{w}$ & $M_{w} / M_{n}$ & Yield (\%) \\
\hline Triton X-114 & 4528 & 1.46 & 84.2 \\
Triton X-100 & 9858 & 1.65 & 86.8 \\
Tween 40 & 2743 & 1.16 & 83.1 \\
Tween 80 & 1776 & 1.04 & 81.7 \\
None & 2286 & 1.07 & 85.1 \\
\hline
\end{tabular}

Reaction conditions: $3 \mathrm{wt} \%$ Novozym $435,55^{\circ} \mathrm{C}, 30 \mathrm{~h}$, solvent-free, 80 $\mathrm{kPa}, 30 \mathrm{mg} / \mathrm{ml}$ surfactants.

\subsection{GPC monitoring of molecular weight}

Figure 4 displays GPC traces of the products within reaction time of $8,16,24$, and $30 \mathrm{~h}$. The data from this analysis allowed the following discussion about the chain growth as a function of time. Compared the peak shapes of 8 and $30 \mathrm{~h}$, we can conclude that the chain buildup was very rapidly. The short-chain oligomer with low molecular weight had begun to build at $8 \mathrm{~h}$, and the peak shapes became better with the reaction process, which showed that the short chains could be polymerized continuously to the long chain polymer. Thus, an uninterrupted increasing of molecular weight was observed. The white solid oligomers of $M_{w}=$ 2300 with perfect polydispersity $\left(M_{w} / M_{n}\right) 1.07$ were ob- tained at $30 \mathrm{~h}$. The homopolymer $\left(M_{w}=5200\right)$ of oligomer $\left(M_{w}=2300\right)$ was obtained after $10 \mathrm{~h}$ by lipase-catalyzed polymerization when the reaction temperature was increased to $70^{\circ} \mathrm{C}$.

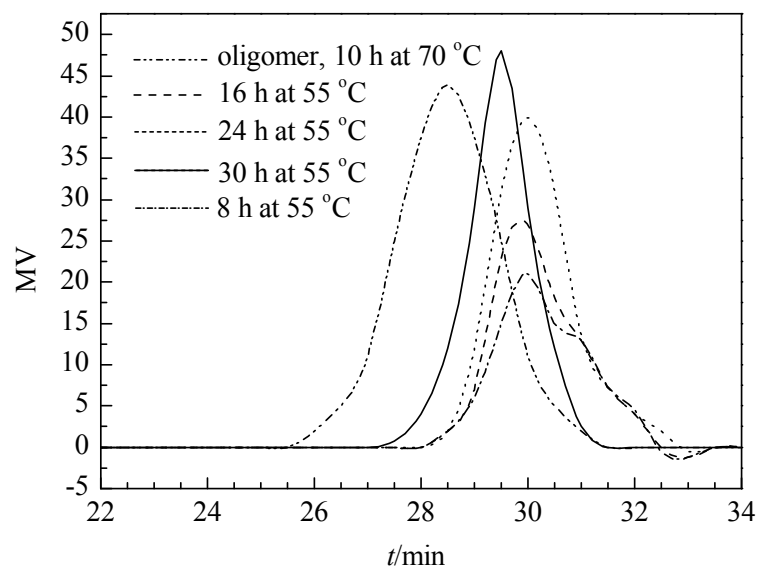

Fig. 4. GPC traces of polymeric products.

The results of GPC traces indicated that the lipase-catalyzed polycondensation of methyl 3-hydroxypropionate should occur by a step-growth mechanism. Our results were consistent with the step-growth kinetics to propagation. Furthermore, both polymerization and alcoholysis reaction occurred simultaneously, although the equilibrium was shifted towards polymer formation by removing methanol under vacuum. Hence, the more details about the polymerization mechanisms needed to be studied further.

\subsection{Reuse of the catalyst and preparative scale experiment}

Due to the insolubility in the reaction system, the biocatalyst lipase could be recovered conveniently for reuse. Novozym 435 was stable in the reaction. It was used repeatedly by filtrating and washing. The repeated reactions were carried out under the same optimal reaction conditions. Figure 5 shows that the Novozym 435 was very stable and its relative activity kept above $95 \%$ throughout 6 batches reactions.

To show the applicability of the lipase-catalyzed polymerization process, a preparative scale experiment with 0.5 mol substrate (about $52 \mathrm{~g}$ ) was performed. The experiment was carried out under the optimum reaction conditions (3 wt $\%$ catalyst; $55^{\circ} \mathrm{C} ; 40 \mathrm{kPa}$; solvent-free reaction system; impeller stirrer at $800 \mathrm{r} / \mathrm{min} ; 48 \mathrm{~h}$ reaction time). The polyhydroxypropionate product with $82.5 \%$ yield was obtained with high molecular weight $M_{w} 9100$, which was probably due to the great intensity of impeller stirrer. The polymeric process was prolonged by stirring sticky solid oligomers 


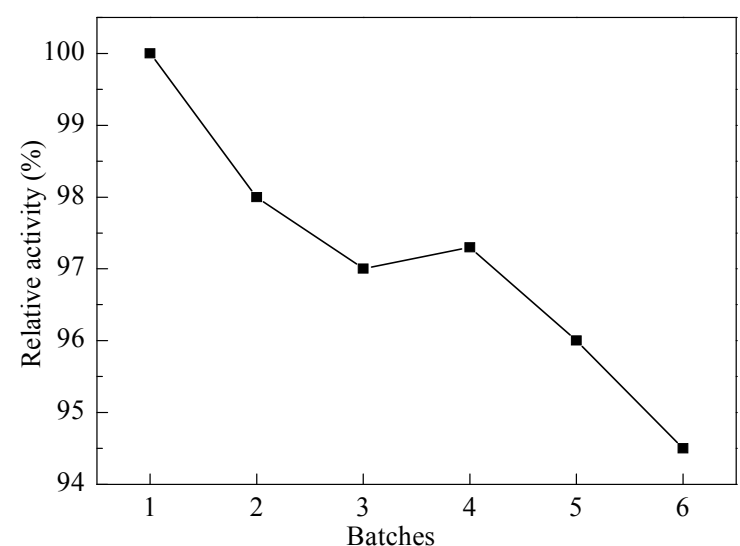

Fig. 5. Reuse of the catalyst in the polymerization. Reaction conditions: $55^{\circ} \mathrm{C}, 30 \mathrm{~h}$, solvent-free, $80 \mathrm{kPa}$.

using impeller stirrer. The degree of polymerization and the molecular weight would be improved by continuous homopolymerization of oligomers. The preparative scale experiment showed good possibility and applicability in the further amplification of production.

\section{Conclusions}

We developed a convenient enzyme-catalyzed polymerization route for synthesizing polyhydroxypropionate, which was different from the traditional biosynthesis route. The polyester could be obtained directly by enzyme-catalyzed polycondensation using inexpensive chemical monomers, which would decrease the production costs efficiently. Compared with the traditional microorganism fermentation process, the products with high purity could be separated conveniently from the enzyme-catalyzed reaction system. In the polymeric reaction, the lipase of Novozym 435 acted as an efficient biocatalyst with high activity and stability. By optimizing reaction conditions, the product yield could be improved and the molecular weight could be controlled, which were crucial for the polymerization. In conclusion, the enzyme-catalyzed polymerization using chemical monomers was a novel method, by which the polymer of PHAs could be obtained conveniently in a mild environment-friendly process.

\section{References}

1 Baki H, Alexander S. Appl Microb Biotech, 2007, 74: 1

2 Valappil S P, Misra S K, Boccaccini A R, Roy I. Expert Rev Med Devices, 2006, 3: 853

3 Chen G Q, Wu Q. Biomaterials, 2005, 26: 6565

4 Anderson A J, Dawes E A. Microbiol Mol Biol Rev, 1990, 54: 450

5 Anderson A J, Williams D R, Taidi B, Dawes E A, Ewing D F. FEMS Microbiol Rev, 1992, 103: 93

6 Chen G Q, Wu Q, Xi J Z, Yu H P. Progr Nat Sci, 2000, 10: 843

7 Byrom D. Trends Biotechnol, 1987, 5: 246

8 Choi J I, Lee S Y. Bioprocess Eng, 1997, 17: 335

9 Uyama H, Kobayashi S. J Mol Catal B, 2002, 19-20: 117

10 Albertsson A C, Srivastava R K. Adv Drug Deliv Rev, 2008, 60: 1077

11 Kobayashi S, Uyama H, Ohmae M. Bull Chem Soc Jpn, 2001, 74: 613

12 Kobayashi S, Uyama H, Kimura S. Chem Rev, 2001, 101: 3793

13 Kobayashi S, Uyama H. Curr Org Chem, 2002, 6: 209

14 Santaniello E, Ferraboschi P, Grisenti P, Manzocchi A. Chem Rev, 1992, 92: 1071

15 Kobayashi S, Shoda S I, Uyama H. Adv Polym Sci, 1995, 121: 1

16 Kaplan D L, Dordick J, Gross R A, Swift G. Enzyme Polym synth, 1998, 684: 2

17 Gross R A, Kumar A, Kalra B. Chem Rev, 2001, 101: 2097

18 Kobayashi S. J Polym Sci A, 1999, 37: 3041

19 Varma I K, Albertsson A C, Rajkhowa R, Srivastava R K. Progr Polym Sci, 2005, 30: 949

20 Dong H, Wang H D, Cao S G, Shen J C. Biotechnol Lett, 1998, 20: 905

21 Gorke J T, Okrasa K, Louwagie A, Kazlauskas R J, Srienc F. J Biotechnol, 2007, 132: 306

22 Knani D, Gutman A L, Kohn D H. J Polym Sci A, 1993, 31: 1221

23 Andreeben B, Steinbuchel A. Appl Environ Microbiol, 2010, 76: 4919

24 Liu J H, Wu H, Xu L W, Chen J, Xia C G. J Mol Catal A, 2007, 269: 97

25 Liu J H, Chen J, Xia C G. J Mol Catal A, 2006, 250: 232

26 Wehtje E, Adlercreutz P. Biotechnol Bioeng, 1997, 55: 798

27 林智健, 李光吉, 龙俊元, 宗敏华. 催化学报( Lin Zh J, Li G J, Long J Y, Zong M H. Chin J Catal), 2011, 32: 123 